\title{
Connectivity in Spanish metapopulation of Dupont's lark may be maintained by dispersal over medium-distance range and stepping stones
}

\author{
Alexander García-Antón ${ }^{1}$, Vicente Garza ${ }^{1}$, Juan Traba ${ }^{\text {Corresp. } 1,2}$ \\ ${ }^{1}$ Terrestrial Ecology Group (TEG-UAM), Department of Ecology, Universidad Autónoma de Madrid, Madrid, Madrid, Spain \\ Centro de Investigación en Biodiversidad y Cambio Global, Universidad Autónoma de Madrid, Madrid, Madrid, Spain \\ Corresponding Author: Juan Traba \\ Email address: juan.traba@uam.es
}

Background: Dupont's Lark is an endangered bird, whose fragmented distribution in Europe is entirely restricted to Spain. This lark, suffering pronounced population decline and range contraction, inhabits steppes that have long been used for grazing sheep and are now threatened by rural abandonment and land use changes. Thus, for conservation of the lark, increasing knowledge about the connectivity of the Spanish metapopulation and identifying the most important connectivity nodes are crucial.

Methods: The study was carried out in Spain, using over 16,000 Dupont's Lark georeferenced observations. We used distance buffers to define populations and subpopulations, based on the available scientific information. We identified potential stepping stones using a MaxEnt probability of presence model. Connectivity was assessed using Conefor software, using the centroid of each subpopulation and stepping stone as nodes. Each node was assigned a quantitative attribute based on total habitat area, within-node habitat quality and internal fragmentation. We evaluated different connectivity scenarios by potential movement thresholds (5-20-100 km) and presence or absence of stepping stones in the network.

Results: Dupont's Lark Iberian metapopulation comprises 24 populations and 100 subpopulations, plus 294 potential stepping stones. Movement thresholds and stepping stones had a strong influence in the potential network connectivity. The most important nodes are located in the core of the metapopulation, which shows connectivity among subpopulations in the different indices and scenarios evaluated. Peripheral populations are more isolated and require stepping stones or medium (20 km) or long (100 $\mathrm{km}$ ) potential movement thresholds to join the network.

Discussion: Metapopulation connectivity may be greater than expected, thanks to stepping stones and potential medium-distance movements. Connectivity is crucial for conservation and can be increased by preserving or improving adequate habitat in the most important nodes. Given the current species decline, steppe habitat should be urgently protected from land use changes and agriculture intensification, at least in the critical subpopulations and stepping stones. Long-term conservation of steppe lands and Dupont's Lark in Spain requires the recovery of traditional grazing and more research on juvenile dispersion. Meanwhile, the conservation of potentially critical stepping stones should be incorporated to management plans. 


\section{Connectivity in Spanish metapopulation of Dupont's}

2 Lark may be maintained by dispersal over medium

3 distances and stepping stones

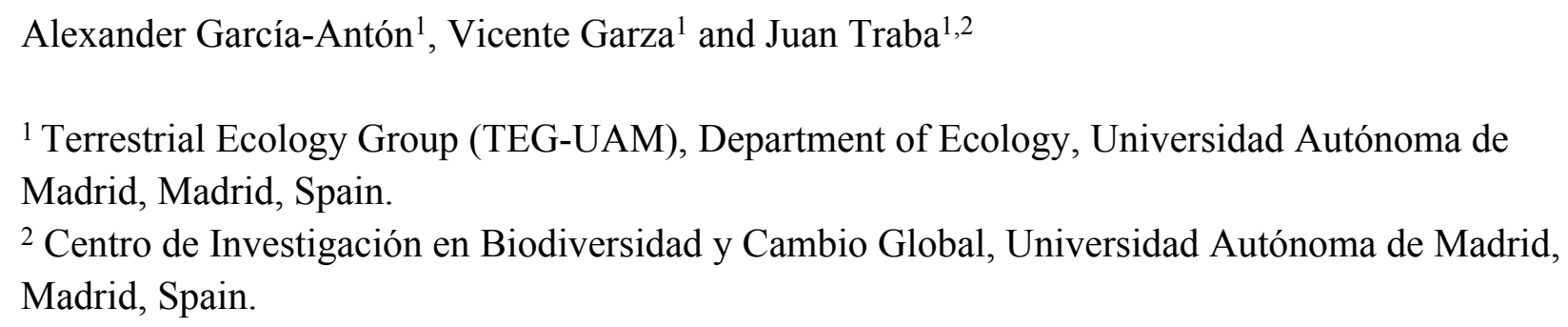

12 Corresponding Author:

13 Juan Traba

14 Department of Ecology, Universidad Autónoma de Madrid, c/ Darwin, 2 C-212, 28049, Madrid, 15 Spain.

16 Email address: juan.traba@uam.es

\section{Abstract}

Background: Dupont's Lark is an endangered bird, whose fragmented distribution in Europe is entirely restricted to Spain. This lark, suffering pronounced population decline and range contraction, inhabits steppes that have long been used for grazing sheep and are now threatened by rural abandonment and land use changes. Thus, for conservation of the lark, increasing knowledge about the connectivity of the Spanish metapopulation and identifying the most important connectivity nodes are crucial.

Methods: The study was carried out in Spain, using over 16,000 Dupont's Lark georeferenced observations. We used distance buffers to define populations and subpopulations, based on the available scientific information. We identified potential stepping stones using a MaxEnt probability of presence model. Connectivity was assessed using Conefor software, using the centroid of each subpopulation and stepping stone as nodes. Each node was assigned a quantitative attribute based on total habitat area, within-node habitat quality and internal fragmentation. We evaluated different connectivity scenarios by potential movement thresholds (5-20-100 km) and presence or absence of stepping stones in the network. subpopulations, plus 294 potential stepping stones. Movement thresholds and stepping stones had a strong influence in the potential network connectivity. The most important nodes are located in the core of the metapopulation, which shows connectivity among subpopulations in the different indices and scenarios evaluated. Peripheral populations are more isolated and require stepping stones or medium $(20 \mathrm{~km})$ or long $(100 \mathrm{~km})$ potential movement thresholds to 39 join the network. 
40 Discussion: Metapopulation connectivity may be greater than expected, thanks to stepping stones and potential medium-distance movements. Connectivity is crucial for conservation and can be increased by preserving or improving adequate habitat in the most important nodes. Given the current species decline, steppe habitat should be urgently protected from land use changes and agriculture intensification, at least in the critical subpopulations and stepping stones. Longterm conservation of steppe lands and Dupont's Lark in Spain requires the recovery of traditional grazing and more research on juvenile dispersion. Meanwhile, the conservation of potentially critical stepping stones should be incorporated to management plans.

\section{Introduction}

Connectivity of animal populations is of major importance for biodiversity conservation and plays a special role when managing threatened species (Crooks \& Sanjayan, 2006; PascualHortal \& Saura, 2006). Both ecosystem functionality and population persistence depend on the degree of connectivity among the habitat patches, which is associated to the movement capacity of the focal species and to the landscape configuration (Pascual-Hortal \& Saura, 2007). Patch isolation relies on factors such as size, distance to neighbours or the degree of permeability of the matrix. In general, small and isolated patches have a lower probability of occupancy than large and connected ones (Levins, 1970; Hanski, 1999a), depending on the ecology of the studied species: minimum patch size required (Vögeli et al., 2011; Shake et al., 2012), dispersal capacity (Rolstad, 2008) or matrix composition (Ricketts, 2002; Vögeli et al., 2010; Watling et al., 2010).

A population can occupy a group of isolated patches (fragments) if they are connected enough to permit dispersal and gene flow, thus forming a metapopulation (Levins, 1969; Hanski, 1998, 1999a; Hanski \& Gaggiotti, 2004). The probability of connection between two fragments depends on the dispersal ability of the species, which is linked to the distance between fragments, and characteristics of the matrix through which dispersal happens (MacArthur \& Wilson, 2001; Whittaker \& Fernandez-Palacios, 2007; Losos \& Ricklefs, 2009). A patch can be completely isolated if the distance is too great for the dispersal ability of the species. In the traditional island biogeography theory, mainland areas are sources of individuals colonizing new areas, but in a metapopulation context immigration may occur from different habitat patches and populations (Hanski, 1998). Metapopulation dynamics will be determined in part by the quality, size, and distances between the fragments. From the connectivity perspective, the loss of a part of the metapopulation can have consequences for the rest, being more or less severe depending on the importance of the lost patch in the whole network (Hanski, 1999a, 1999b).

Graph-based models are used to describe the movement-among-patch potential in a metapopulation comprising scattered habitat nuclei (patches or fragments) within an unsuitable matrix (Pascual-Hortal \& Saura, 2006; Bodin \& Saura, 2010; Saura \& Rubio, 2010), and they offer quantitative information to identify critical patches for the maintenance of the functionality of the whole network (Calabrese \& Fagan, 2004; Visconti \& Elkin, 2009). A graph structure is based on two elements: nodes and links between them (Saura \& Torné, 2009). Nodes represent suitable habitat patches occupied by the species or those acting as stepping stones (Loehle, 
80

81

82

83

84

85

86

87

88

89

90

91

92

93

94

95

96

97

98

99

100

101

102

103

104

105

106

107

108

109

110

111

112

113

114

115

116

117

118

2007). Links are the connections between nodes, frequently estimated as the distance between them. Each node is also given a numerical value that defines its quality within the network; usually, habitat area or other factor that describes focal species requirements (Mazaris et al., 2013; Pereira et al., 2017).

Dupont's Lark (Chersophilus duponti; Vieillot, 1824, family Alaudidae) is a paradigmatic case for the study of connectivity, given the high degree of both natural and human-induced fragmentation of its habitat in Spain (García-Antón et al., 2019), and its strong specialization (Suárez, 2010). It is a small $(\sim 17.5 \mathrm{~cm}, \sim 38.5 \mathrm{~g})$ bird that is extremely elusive, rare and, in Europe, only found in Spain, though it also occurs in northern Africa (de Juana \& Suárez, 2020). The Spanish population is isolated from the African one and they are genetically and morphologically different (García et al., 2008, Garcia-Antón et al., 2018). It is only found on mainly plain steppes ( $<15 \%$ slope), that in Spain have long been used by humans, especially for grazing sheep. Sheep tend to keep the vegetation low $(<40 \mathrm{~cm})$ and cause a large proportion of bare ground (Garza \& Suárez, 1990; Martín-Vivaldi et al., 1999; Garza et al., 2005; Garza et al., 2006; Nogués-Bravo \& Agirre, 2006; Seoane et al., 2006).

Isolation of populations is one of the major concerns for Dupont's larks in Spain (Garza et al., 2004; Íñigo et al., 2008; Méndez et al., 2011). Its fragmented distribution may function as a metapopulation (Gómez-Catasús et al., 2018a; García-Antón et al., 2019; Traba et al., 2019), with different fragments or group of fragments having their own demographic parameters (Pérez-Granados et al., 2017), with individual movements connecting them (García-Antón et al., 2015) and recolonization events of extinct patches (Bota et al., 2016). The sample bias toward adult males associated with the capture method (Garza et al., 2003; Suárez, 2010) provides little information regarding other age and sex classes. Adults are sedentary (Cramp \& Simons, 1980; Suárez et al., 2006) and juveniles may disperse (García-Antón et al., 2015). The persistence of small and isolated subpopulations, however, suggests that medium to longer distance movements may often occur, from 4 to $300 \mathrm{~km}: \sim 5 \mathrm{~km}$ (Pérez-Granados \& López-Iborra, 2015); $8 \mathrm{~km}(V$. Garza, unpublished data); $33 \mathrm{~km}$ (García-Antón et al., 2015). Some recent records reveal the existence of longer movements: $37 \mathrm{~km}$ (recolonization of Timoneda de Alfés, Lérida; Bota et al., 2016), $80 \mathrm{~km}$ (Salinas de Marchamalo, Murcia; García \& Requena, 2015) and 99 km (Albufera de Valencia; Dies et al., 2010; Balfagón and Carrion Piquer, 2021), these being the minimum distance to the nearest occupied locality. Historic observations reveal even longer distance events: $127 \mathrm{~km}$ (Barcelona), $241 \mathrm{~km}$ (Trebujena-Sanlúcar, Cádiz), and up to $324 \mathrm{~km}$ (Marismas del Odiel, Huelva), among others (see Supplemental Table S1).

Dupont's Lark occupies an area of around 1,000 km² in Spain, while another $965 \mathrm{~km}^{2}$ of unoccupied habitat is available (Garcia-Antón et al., 2019), which suggests that the metapopulation may be better connected than expected if this area is used as stepping stones. Recent studies indicate a generalized and pronounced decline in most Spanish subpopulations (Gómez-Catasús et al., 2018a) and in their overall distribution (García-Antón et al., 2019). As fragmentation of the steppes continues, which is the main threat for Dupont's Lark (Ínigo et al., 
119 2008), identification of critical patches for the maintenance of the metapopulation connectivity is

120 required for the conservation of the species.

121 Here we address a detailed analysis of Dupont's Lark metapopulation connectivity in

122 Spain, to provide a useful tool for the management and conservation of this threatened species.

123 We hypothesize that the metapopulation must be better connected than expected, as connectivity

124 and gene flow would explain the maintenance of the smallest and most isolated subpopulations,

125 More specifically, we i) update the cartography of populations and subpopulations of Dupont's

126 Lark in Spain; ii) identify both vulnerable and critical nodes from the connectivity point of view

127 for the conservation of the metapopulation; iii) assess the role of unoccupied but adequate

128 regions in the metapopulation, testing the effect of different dispersal distance thresholds; iv)

129 evaluate the degree of isolation of each subpopulation; and v) propose adequate conservation

130 measures for the maintenance of the metapopulation.

131

132 Materials \& Methods

133 The ethics committee of Animal Experimentation of the Autonomous University of Madrid as an

134 Organ Enabled by the Community of Madrid (Resolution 24th September 2013) for the

135 evaluation of projects based on the provisions of Royal Decree 53/2013, 1st February, has

136 provided full approval for this purely observational research (CEI 80-1468-A229).

137 Species observations

138 We used the database of georeferenced observations of Dupont's Lark updated to 2017,

139 including our unpublished data (TEG-UAM) and adding all available external records (Traba et

140 al., 2019). We gathered a total of 17,755 Dupont's Lark locations corresponding to the temporal

141 series of 1985-2017, both years included. We considered as recent those observations belonging

142 to the post-2000 period ( $\mathrm{n}=17,282$; 97\%), when the II National Census was carried out (2004-

143 2006; Suárez, 2010). This work allowed to standardize the field work using the territory mapping

144 census method, which corrects the bias detected in previous works (Garza et al., 2003; Pérez-

145 Granados \& López-Iborra, 2013). We considered that pre-2000 observations do not represent

146 current species distribution patterns (see García-Antón et al., 2019), and so they were not

147 included in this analysis.

148 Among the post-2000 locations, 14,203 came from our data (TEG-UAM), while the rest

$149(\mathrm{n}=3,079)$ was provided by other administrations, research entities and individual

150 ornithologists. We only used breeding season (February - July) observations. We excluded

151 anomalous observations (clearly unoccupied or that only indicate moving animals). This resulted

152 in 16,676 observations that we analyzed. These observations are aggregated in clusters,

153 coinciding with the natural aggregation of habitat patches, though we have considered them as

154 geographically independent for connectivity analyses.

155 Species habitat

156 To build a map of Dupont's Lark habitat at a national scale we used CORINE land cover (CLC)

157 inventory from the Copernicus European program, following the same method as in the

158 distribution model (García-Antón et al., 2019). First, we intersected the 16,676 georeferenced 
159 observations with CLC 2006 layer (maintaining temporal correspondence with the period in

160 which the majority of the observations belonged to, i.e., II National Census, 2004-2006; Suárez

161 2010). We selected the land use categories that accumulated $95 \%$ of the observations (see a

162 description in Supplemental Table S2), interpreting them as the habitat preferred by the species.

163 Then, we extracted those categories from the most updated CLC available (2012) to get the

164 current habitat map in Spain. To improve precision, we removed surfaces with slopes $>15 \%$

165 (unsuitable habitat) and patches $<20$ ha (minimum threshold for species occupancy; Suárez,

166 2010). We used this map to estimate the habitat area within subpopulations and stepping stones

167 (used as nodes in the connectivity model, see below). More details on the map building can be

168 found in Garcia-Antón et al. (2019).

\section{Criteria for the definition of locality, subpopulation and population}

170 We defined three sequentially hierarchical levels of actual occupancy by the species based on the map of 16,676 observations and distance thresholds published to date (Laiolo, 2008; Suárez, 2010; Vögeli et al., 2010; Méndez et al., 2014; García-Antón et al., 2015; Bota et al., 2016), as well as our unpublished data. Those were: locality, subpopulation and population.

We defined a locality as the area delimited by observations separated less than $1 \mathrm{~km}$, distance that is known to be traveled by territorial males (Suárez, 2010; Vögeli et al., 2010). Data from capture-recapture of territorial adults indicate they are strongly sedentary, with regular movements < 3 km (Laiolo et al., 2007; Vögeli et al., 2008; Suárez, 2010; Vögeli et al., 2010). Bioacoustic data suggest cultural similarity and adult males contact at a distance of $5 \mathrm{~km}$ (Laiolo, 2008), supported by the recovery of two marked adults at $\sim 5$ and $6 \mathrm{~km}$ in Rincón de Ademuz, Valencia (Pérez-Granados \& López-Iborra, 2015). There is only one record of an adult out of this range, recaptured at $13 \mathrm{~km}$ from its capture location ( . Garza, unpublished data). Thus, we established $5 \mathrm{~km}$ as the plausible threshold for resident movements. Therefore, a subpopulation was delimited by observations separated $5 \mathrm{~km}$ or less. Finally, a population was considered as the set of subpopulations separated by a maximum distance of $20 \mathrm{~km}$, following a conservative criterion and accounting for the few available data on juvenile dispersal (up to $20 \mathrm{~km}$ in Vögeli et al., 2010, $33 \mathrm{~km}$ in García-Antón et al., 2015). This upper level represents those entities that, despite being connected sporadically would maintain a high genetic similarity due to individuals exchange (Méndez et al., 2011; Méndez et al., 2014). We used a GIS software (QGIS.org, 2021) to build the correspondent buffers of $0.5,2.5$ and $10 \mathrm{~km}$ over the observations layer (Fig. 1).

\section{Definition of stepping stones}

We also identified those areas that, despite being unoccupied by the species, could be potentially used and relevant in the connectivity process due to their high probability of presence, as shown in the distribution model (Garcia-Antón et al., 2019). To do so, we used the 1x1 km cells considered to be of potential distribution $(n=5,575$; those that accounted for a probability value higher than the mean of the 1,370 ones with confirmed presence, see García-Antón et al., 2019). After excluding cells that included buffers (that were included in the subpopulation layer), unoccupied potential habitat comprised 3,597 1x1 km cells. Adjacent cells were grouped into clusters, resulting in 902 independent entities. Following a conservative criterion, we removed 
199 those formed by a single $1 \times 1 \mathrm{~km}$ cell, reducing it to 294 polygons. More details on the stepping

200 stones building can be found in García-Antón et al. (2019).

201 Movement scenarios

202 The compilation of historic and recent Dupont's Lark observations out of the known breeding

203 range (Supplemental Table S1) reveals the existence of longer displacements than the thresholds

204 defined previously, considered as rare events corresponding to sporadic long-distance

205 movements. Taking into account all together, we defined three potential scenarios (see below):

206 short $(5 \mathrm{~km})$; medium $(20 \mathrm{~km})$ and long $(100 \mathrm{~km})$ movements thresholds.

207 Nodes and habitat attribute

208 We built the connectivity model at the subpopulation level, to obtain a more detailed result and

209 considering that subpopulations, better than populations, constitute the metapopulation

210 functional units, each with its own extinction risk and connectivity probability with the rest. This

211 way, our network included one node located in the centroid of each subpopulation and stepping

212 stone.

213 Each node was assigned a quantitative value that estimates its quality or importance in

214 the network. We defined such attribute as Available Habitat Surface (AHS) and calculated it

215 considering the surface of adequate habitat, its quality and its degree of fragmentation by

216 intersecting the species habitat map (see above) with the subpopulation and stepping stone layer.

217 Population size (number of territorial males) was not included in the AHS attribute as stepping

218 stones account for no data on population size. Besides, we avoided bias in the result of our

219 connectivity model toward historically occupied localities, regardless of their position in the

220 actual metapopulation configuration Therefore, the AHS was defined as following:

221

222

223

224

225

226

227

228

229

230

231

232

233

234

235

236

237

238

$$
A H S=H S * H Q * 1 / N P
$$

Where HS (habitat surface) is the total surface of adequate habitat within the subpopulation (or stepping stone), calculated as the sum of all habitat patches within each one; HQ is habitat quality, estimated as the mean value of probability of presence of the intersecting $1 \times 1 \mathrm{~km}$ cells, as estimated in the MaxEnt model (García-Antón et al., 2019); and NP is the number of habitat patches within the subpopulation or stepping stone, as a measure of fragmentation. This way, each node obtained a value positively associated to its surface, quality and continuity of habitat.

To calculate the network links, we used the closest linear distance between borders of each pair of subpopulations and stepping stones, using a nearest neighbor algorithm in GIS software. We did not use distances between centroids because they do not reflect true distances that a bird would travel between patches, especially for larger patches.

\section{Connectivity model}

We used software Conefor (Saura \& Torné, 2009) to generate the connectivity model, which is widely used to analyse network structures (Saura et al., 2011; Vergara et al., 2013; Grafius et al., 2017). It builds the model in a two-step process: First, it calculates a connectivity index for the whole network (PC, probability of connection). It is based on node quality (AHS attribute), the distance between nodes, and dispersal capacity. Then, it removes each node independently 
239

240

241

242

243

244

245

246

247

248

249

250

251

252

253

254

255

256

257

258

259

260

261

262

263

264

265

266

267

268

269

270

271

272

273

274

275

276

277

278

and calculates the loss of PC due to that removal (dPC), obtaining an estimation of the contribution of each node to the global structure.

Conefor also allows the comparison between different general scenarios by means of the equivalent connectivity index (EC, see Saura \& Torné, 2009), a modification of PC provided in the same units than the node attribute (see Saura et al., 2011; Saura \& Torné, 2009). Prior to subsequent analyses, we compared scenarios resulting from the different movement thresholds considered (see above): short $(5 \mathrm{~km})$, medium $(20 \mathrm{~km})$ and long distance $(100 \mathrm{~km})$ and the presence or absence of stepping stones in the network (building the network with two different node maps, one including exclusively subpopulations and another one with the addition of all the stepping stones).

To evaluate the importance of each node for the network, $\mathrm{dPC}$ is fractioned into three more specific metrics: $\mathrm{dPC}_{\text {intra }}, \mathrm{dPC}_{\text {flux }}$ and $\mathrm{dPC}_{\text {connector }}$ (Pascual-Hortal \& Saura, 2006). The fraction $\mathrm{dPC}_{\mathrm{intra}}$ refers to the internal quality of the node (intra-patch connectivity), as it had been defined through the attribute considered (in this case, AHS). Thus, it is independent of the distance to others nodes and its spatial position in the network. $\mathrm{dPC}_{\text {flux }}$ is a value of inter-patch connectivity, giving information about the degree of flow that each node generates within the network; this index considers all the connections in which each node is either the origin or the destination points, as well as the quality of such connections (based on the AHS of the nodes involved). So, $\mathrm{dPC}_{\text {flux }}$ depends on the spatial position of each node within the network, but also on the quality of those nodes it is connected to. Finally, $\mathrm{dPC}_{\text {connector }}$ adds a second value of interpatch connectivity, indicating the contribution of each node to the connectivity among the rest. This index provides information about the importance of each node for the maintenance of other nodes or group of nodes connectivity, that is, if it acts as a stepping stone whose absence would implicate that others increase their isolation or remain connected through a worse route (with a longer distance or passing through lower quality nodes). The total value of $\mathrm{dPC}$ is just the sum of these three fractions, so it gives a general value to each of the nodes in the network.

Finally, we calculated the matrix of probability of connection for each pair of nodes (subpopulations and stepping stones), what allows building connectivity maps for all different scenarios considered.

\section{Results}

\section{Populations, subpopulations and stepping stones}

Based on the map of post-2000 observations and after the application of considered criteria we obtained 123 subpopulations, 23 of which are currently extinct, considering the most recent field data, updated to 2019. After removing them, we defined a present network of 100 subpopulations, 24 populations, plus the already mentioned 294 potential stepping stones (Fig. 2, Supplemental Table S3, Supplemental Data S1).

The metapopulation structure (Fig. 2) is formed by a core region comprising the largest population: Iberian Range - Ebro Valley (considered two independent populations to date, Suárez, 2010). Northwards, the metapopulation shows a myriad of small populations scattered 
279 through the Iberian Range (provinces of Soria, Zaragoza, Teruel, Navarra and Huesca), perhaps

280 remnants of a historical more continued distribution. Further east and more isolated, the only

281 Catalonian population: Alfés (Lérida province). Through the west (Zamora province) three small

282 populations exist, with an apparent greater degree of isolation due to their distance with the core.

283 Southwards, a group of 12 disperse populations and progressively more isolated from the core of

284 the distribution are distributed along the provinces of Valencia, Cuenca, Toledo, Albacete,

285 Murcia, Almería and Granada (Fig. 2, Supplemental Data S1).

286 Global connectivity under different scenarios

287 The EC index increased with the movement threshold and with the presence of stepping stones

288 (Supplemental Table S4). Because both movement threshold and stepping stones were important 289 for connectivity, we include them both in all subsequent analyses.

290 Node classification by internal importance index ( $\left.\mathrm{dPC}_{\text {intra }}\right)$

291 The subpopulations of Monegros (Z) and Blancas (TE) stand out with the highest $\mathrm{dPC}_{\text {intra }}$ values

292 (Table 1), meaning the best relation between habitat surface, quality and continuity (AHS

293 attribute). The complete list (Supplemental Data S2) shows two stepping stones in the first 20

294 positions: Castronuño (in Valladolid province, with the same $\mathrm{dPC}_{\text {intra }}$ value than the $10^{\text {th }}$ ranked

295 subpopulation) and Bardenas 2 (Navarra province).

296 Node classification by importance for flow generation ( $\mathrm{dPC}_{\text {flux }}$ )

297 The subpopulations of Monegros (Z) and Blancas (TE) were again the most important ones for

298 this fraction, together with Torralba de los Frailes (TE), Paramera de Molina (GU) and Gelsa

299 (Z) (Table 2). These subpopulations were those with more connections as starting or ending

300 points, based on $\mathrm{dPC}_{\text {flux }}$ values. No stepping stones were important when considering medium

301 and long movement thresholds ( 20 or $100 \mathrm{~km}$ ), but they appeared to be relevant in the scenario

302 of short movements (5 km): Monegrillo 2 (Z), Alfajarín $1(\mathrm{Z})$ and Torralba de los Sisones (TE)

303 (top 10 ranking in Table 2, complete dataset is available in Supplemental Data S2 and S3).

304 Node classification by importance for connectivity maintenance ( $\mathrm{dPC}_{\text {connector}}$ )

305 Three subpopulations, all included in the Iberian Range - Ebro Valley population, were the most

306 important due to their function as connectivity nodes between others: Paramera de Molina (GU),

307 Layna (SO) and Altos de Barahona (SO) (Table 3), followed by Gelsa (Z) and Altiplano de

308 Teruel (TE), which were also present in all the scenarios. Four stepping stones were in top

309 positions in the list: Alba, Rubielos de la Cérida, Ojos Negros 1 and Hoz de la Vieja, all of them

310 in Teruel province and within the Iberian Range - Ebro Valley population: (top 10 ranking in

311 Table 3, complete dataset is available in Supplemental Data S2 and S3).

312 Node classification by general importance index (dPC)

313 Taking into account the sum of all previous fractions, Monegros (Z) and Blancas (TE) were

314 highlighted as the most important subpopulations, followed by Torralba de los Frailes (TE) and

315 Paramera de Molina (GU), all of them within the Iberian Range - Ebro Valley population (Table

316 4). When considering the presence of stepping stones, three important areas for the network

317 connectivity were detected, also belonging to the same population: Alba (TE), Rubielos de la

318 Cérida (TE) and Cuerlas 1 (Z), which appear within the 10 most important nodes (Table 4). See

PeerJ reviewing PDF | (2021:01:56969:3:0:NEW 8 Jul 2021) 
319 Fig. 3 for a graphical view in an intermediate situation (scenario 5: $20 \mathrm{~km}$ movements and

320 presence of stepping stones); the complete dataset is available in Supplemental Data S2 and S3.

\section{Connectivity network}

322 The degree of connectivity showed a strong variability under the different scenarios, highlighting

323 the influence of potential movement thresholds and presence/absence of stepping stones in the metapopulation dynamics (Supplemental Data S2 contains the complete matrix, with the

325 probability of connection for each pair of nodes under each scenario).

The most conservative situation (scenario 1: $5 \mathrm{~km}$ movements and absence of stepping stones) showed an extreme isolation, with connections among nearby subpopulations only in the metapopulation core (Fig. 4). Moreover, these connections seemed to be weak (0.001-20\% probability), and lacking inter-population connections. In this situation, all the subpopulations outside of the Iberian Range - Ebro Valley population would be completely isolated. For this movement threshold, the presence of stepping stones would not be enough to connect the outermost subpopulations (scenario 4, Fig. 4).

For potential movements up to $20 \mathrm{~km}$ (scenario 2, Fig. 4), the situation changed notably. Despite the connections among nearby subpopulations continued being of low-to-medium probability, inter-subpopulation connectivity occurred within the Iberian Range - Ebro Valley population and within the western populations. With the presence of stepping stones (scenario 5, Fig. 4), high probability connections (over 80\%) were frequent in near all the subpopulations within and north to the Iberian Range - Ebro Valley population. The most western populations increased their inter-subpopulation connectivity but remained unconnected with the metapopulation core. The situation of the southern part of the distribution remained dramatically unconnected, even considering the presence of stepping stones (scenario 5, Fig. 4).

Only with potential movements up to $100 \mathrm{~km}$ (scenarios 3 and 6, Fig. 4), Dupont's Lark threshold, the absence of stepping stones (scenario 3) would result in weak connections of the western and southern subpopulations with the metapopulation core.

\section{Discussion}

The criteria applied in this work for the definition of localities (habitat patches separated by less than $1 \mathrm{~km}$ ), subpopulations (group of localities separated $5 \mathrm{~km}$ or less) and populations (set of subpopulations separated by a maximum distance of $20 \mathrm{~km}$ ) led to a Dupont's Lark metapopulation in Spain formed by 24 populations and 100 subpopulations. This metapopulation is probably dynamic and therefore should be periodically updated with continuous monitoring. Twenty-three additional subpopulations became extinct in the last two decades and should be regularly monitored to verify possible recolonizations.

Dupont's Lark seems not to fit a classic Levins model of colonization-extinction balance. contraction process from the peripheral subpopulations to the core of the distribution. Many adequate habitat patches $(n=294)$ are spread out along the distribution range, although they are heterogeneously distributed. The distant western populations might be better connected than 
359

360

361

362

363

364

365

366

367

368

369

370

371

372

373

374

375

376

377

378

379

380

381

382

383

384

385

386

387

388

389

390

391

392

393

394

395

396

397

398

expected due to stepping stones. The southern range, however, is critically isolated and where the majority of recent subpopulation extinctions occurred.

Through this study we indicate stepping stones and subpopulations that are critical for connectivity. This information can be used by management to avoid increased habitat loss. Conservation measures should include steppe land habitat protection: avoiding infrastructures installation and land use changes, restoring habitat structure with active management and introducing traditional grazing to allow long-term conservation.

While dispersal mechanisms are poorly understood, our results suggest that movement over medium distances $(\sim 20 \mathrm{~km})$ with stepping stones together help explain why small and isolated populations persist, rather than become extinct as previously predicted (Traba et al., 2011; Suárez and Carriles, 2010; Laiolo et al., 2008). This is supported by a recent study in Rincón de Ademuz (Valencia, eastern Spain), which obtained only one recovery out of 26 juvenile individuals marked, suggesting that juveniles either leave their natal site and disperse, or their survival rate is very low (Pérez-Granados et al., 2021).

\section{Populations, subpopulations and stepping stones}

Our results indicate that a large, single population comprises what was previously thought to be the two main populations (Iberian Range, Ebro Valley). The map of subpopulations indicates continuity in the core of the metapopulation and has a strong degree of fragmentation and isolation southwards and in the western range. Our results support the high vulnerability of the peripheral subpopulations, as showed previously in the Ebro Valley (Vögeli et al., 2010) and in genetic analysis (Méndez et al., 2011), which are more prone to extinction (Méndez et al., 2014; Gómez-Catasús et al., 2018a).

While there are many potential stepping-stones (almost 300), they are still likely to be important for metapopulation dynamics. Most of them are in the easternmost distribution (Teruel and Zaragoza provinces). The lack of stepping stones along the southern range helps to explain the dramatic trends of the southernmost subpopulations (Gómez-Catasús et al., 2018a). The apparently strict isolation of the western range (Zamora province) may be surprisingly wellconnected due to the many stepping-stones (Fig. 2). Most of the areas along the metapopulation with apparent optimal habitat but absence of the species (García-Antón et al., 2019) are considered as stepping stones in this work, and they might play a role in the species movements. Whether these areas correspond to empty patches in a classic colonization-extinction balance (Levins 1969) remains unknown. However, population turnover in Dupont's Lark seems to be extremely rare in both metapopulation (Garcia-Antón et al., 2021, under review) and local scales (Gómez-Catasús et al., 2018b). To our knowledge, just one known subpopulation has been recolonized after going extinct (Bota et al., 2016). Intensive field work in the Iberian Range along the study period has recorded one single habitat patch (within a known locality) reoccupied (own data). Rather than a classical Levins model, Dupont's Lark metapopulation could adopt a source-sink structure (Hanski, 1998, 1999a). The smaller and more isolated subpopulations would be in a higher risk of extinction due to its lower connectivity with the core of the distribution, besides other risks associated to its lower size. More than $50 \%$ of the Iberian 
399

400

401

402

403

404

405

406

407

408

409

410

411

412

413

414

415

416

417

418

419

420

421

422

423

424

425

426

427

428

429

430

431

432

433

434

435

436

437

438

subpopulations have less than 5 individuals (Traba et al., 2019), which from a genetic and demographic point of view suggests low medium-term viability, if there is no connection with other subpopulations (Méndez et al., 2011, 2014).

Those subpopulations that went extinct during the post-2000 period ( $\mathrm{n}=23$, which means $19 \%$ of the extant subpopulations at the beginning of the century) could correspond to stochastic factors or to changes in habitat quality (Hanski, 1999a). In the first case, such patches would be immediately available for recolonization, as the one recorded by Bota et al. (2016) in Alfés (Lérida) in 2015. In the latter, that subpopulation would be unavailable for recolonization until habitat was restored. There are two main factors promoting habitat loss in the case of Dupont's Lark. First, the abandonment of extensive grazing leads to plant succession and transformation of the steppe land habitat (Peco et al., 2012, Ínigo et al., 2008; Gómez-Catasús et al., 2019), in addition to decreasing habitat quality due to food (arthropod) availability linked to sheep deposition (Gómez-Catasús et al., 2019; Reverter et al., 2019). Second, direct habitat destruction due to land use changes, mainly wind farms (Gómez-Catasús et al., 2018b) and ploughing (Garza et al., 2004; Ínigo et al., 2008), and new habitat changes expected to appear in the near future (wind farms and solar photovoltaic installations; Serrano et al., 2020).

Therefore, two key elements are crucial for Dupont's Lark conservation: habitat maintenance in the areas inhabited by the species (or those considered important for the connectivity network) and the promotion of active management to guarantee long-term habitat persistence. Recent initiatives in this direction have been positive (LIFE Ricotí in Soria, local projects in Valencia region; see a revision in Traba et al., 2019), and will be a useful tool for key areas (such as critically isolated subpopulations or important stepping stones). Anyway, longterm effective measures for habitat and species conservation should include the promotion of traditional sheep grazing, in order to avoid dramatic plant structure changes and maintain habitat functionality. These measures should be considered, at least, in the most critical connectivity nodes.

Regarding the extinct subpopulations, only 7 of 23 have become stepping stones based on our habitat-suitability criteria (Supplemental Data S4). This result suggests that low habitat quality (i.e. low food availability, changes in vegetation structure) in those areas may have contributed to the local extinction of the species, in addition to isolation. Indeed, 14 out of these 23 extinct subpopulations are located in the southern range (Fig. 2), where isolation is more accused, following a centripetal contraction process from the periphery to the metapopulation core (García-Antón et al., 2021, under review).

In Supplemental Data S1, S2, S3 and S4 we offer detailed data and updated cartography of the metapopulation that can constitute a useful guide for the different regional administrations, which have legal obligations for the conservation of Dupont's Lark in Spain. Management coordination and common guidelines are of vital importance in the case of Dupont's Lark, as several regional administrations are affected by its distribution and share populations or subpopulations.

\section{Global connectivity under different scenarios}


439 Despite the apparent strong fragmentation and high degree of isolation of Dupont's Lark

440 metapopulation, our results suggest two elements that seem to be relevant for the connectivity of

441 the whole network. These factors may contribute to explain the prevalence of the smallest and

442 most isolated subpopulations, which were expected to be extinct based on the population

443 viability models (Laiolo et al., 2008; Suárez, 2010), genetic structure (Méndez et al., 2011,

444 2014), and data on the general situation of the species (Suárez, 2010; Traba et al., 2019). First,

445 the large area of vacant adequate habitat (García-Antón et al., 2019), that should be interpreted

446 as a network of stepping stones unnoticed to date. The size of this stepping stone network

447 approximately equals the size of the occupied range of Dupont's Lark (around 1,000 km²;

448 García-Antón et al., 2019). The Equivalent Connectivity index (EC) comparison (Supplemental

449 Table S4) showed the lowest value of EC for scenario 1 (5 km movement threshold without

450 stepping stones), while EC for scenario 6 (100 km movement threshold with stepping stones) had

451 the highest value. For each scenario, EC was always higher when adding stepping stones than

452 increasing potential movements to the next threshold. Therefore, the role of these unoccupied

453 potential areas seems crucial for the functionality of the network and could have even a stronger

454 influence than the movement capacity of the species (Supplemental Table S4). In other words,

455 even if we consider Dupont's Lark as a strongly sedentary species with sporadic medium-

456 distance movements, the metapopulation could be connected thanks to the presence of stepping

457 stones. The relative low values of stepping stones in $\mathrm{dPC}_{\text {intra }}$ (Table 1) but higher ones in $\mathrm{dPC}_{\text {flux }}$

458 and $\mathrm{dPC}_{\text {connector }}$ (Tables 2 and 3 ) suggest that these patches may have lower habitat quality than

459 occupied subpopulations (based on the AHS attribute), thus being unsuitable for occupancy, but

460 maintaining a high relevance for the metapopulation connectivity.

461 On the other hand, results of the simulation of different movement thresholds (Fig. 4)

462 suggest that 2-5 km maximum dispersal distance assumed previously (Laiolo et al., 2007; Vögeli

463 et al., 2008; Vögeli et al., 2010; Suárez, 2010) could have undervalued actual dispersal ability of

464 the species. Recent records of longer movements, that could correspond to juvenile dispersal

465 (García-Antón, 2015), recolonization (Bota et al., 2016) or sporadic long-distance movements

466 (García and Requena, 2015, Dies et al., 2010, Balfagón and Carrion Piquer, 2021), as well as

467 historical records summarized in Supplemental Table S1, point to medium to large distance

468 events that could be contributing to slow down local extinction as fast as predicted by the

469 viability models (Laiolo et al., 2007; Suárez, 2010).

470 Node importance and AHS attribute

$471 \mathrm{dPC}_{\text {intra }}, \mathrm{dPC}_{\text {flux }}$ and $\mathrm{dPC}$ indicated the same most important nodes: Monegros (Z), Blancas (TE),

472 Torralba de los Frailes (TE) and Paramera de Molina (GU), all of them located in the Iberian

473 Range - Ebro Valley population. The conservation of these top ranked subpopulations is

474 imperative to ensure the conservation of the metapopulation, as it is also crucial to focus on the

475 third fraction of $\mathrm{dPC}\left(\mathrm{dPC}_{\text {connector }}\right)$. In the case of Dupont's Lark, in which isolation may

476 constitute a critical factor for the species conservation, the loss of those subpopulations with a

477 higher value in $\mathrm{dPC}_{\text {connector }}$ could implicate the subsequent extinction of other subpopulations or

478 groups of subpopulations, so they should be considered of highest priority. Several nodes of the

PeerJ reviewing PDF | (2021:01:56969:3:0:NEW 8 Jul 2021) 
479 Iberian Range close to the geographical centroid of the metapopulation are included in this set, 480 mainly Layna (SO), Paramera de Molina (GU) and Altos de Barahona (SO), as well several 481 stepping stones that are also among the top ranked nodes: Alba, Rubielos de la Cérida, Ojos 482 Negros 1 and Hoz de la Vieja, among others (Table 3).

483 Finally, the particular case of the military National Training Centre of San Gregorio, a 484 few km North of Zaragoza city, must be considered. This area holds around 34,000 ha of mostly 485 continuous steppe habitat and due to its huge extension it might certainly constitute one of the 486 most important nodes of the connectivity network. In determining stepping-stones, we identified habitat (stepping stones Zaragoza 1, 3, 4, 5, 6, Supplemental Data S4) that is potentially important, and should be treated as such by the regional administration of Aragón.

Supplemental Data S2 includes the complete lists of node importance by province in all the scenarios considered and should constitute a useful management tool. Each regional administration should consider the most important nodes within its territory, either subpopulations or stepping stones, of high priority and concern. These areas should be included in national and/or regional species conservation plans, as their protection and management seem to be crucial for the maintenance of the species at a national scale, and coordinated measures between neighbour administrations are needed. Stepping stones require special attention, as they are relevant for their spatial and habitat features, but not for the presence of the species, which may difficult the application of conservation measures.

499

500

501

502

503

504

505

\section{Connectivity network}

In the most restrictive scenario (movements of $5 \mathrm{~km}$ and absence of stepping stones), the subpopulations were almost totally isolated, except for the low probability connections within the Iberian Range - Ebro Valley. Assuming a medium movement threshold of $20 \mathrm{~km}$, a significant increase of connections appears within the central distribution, though their probability continued being low. Thus, the uttermost western populations seem to be isolated and their persistence depend on the presence of stepping stones. The most unfavorable situation is in the southern subpopulations, which remain completely isolated without movements of $100 \mathrm{~km}$.

The strong population decline of the species (Gómez-Catasús et al., 2018a), its current and future distribution (García-Antón et al., 2019), and the genetic analyses (Méndez et al., 2011; Méndez et al., 2014) indicate important degree of isolation. But, at the same time, small and isolated peripheral subpopulations persist. Therefore, we suggest that some combination of our scenarios is most likely. Based on movements of the different age classes, and with the little information on juvenile capture-recapture, we suggest that adult movements less than $1 \mathrm{~km}$ are very likely (high probability), and so intra and inter-sexual communication at this distance must be common. Adult movements between 1 and $5 \mathrm{~km}$ could be mid-to-low probability events; those between 5 and $20 \mathrm{~km}$, of low probability; and those over $20 \mathrm{~km}$ must be considered highly improbable events. Juveniles are presumable the dispersive fraction of the population, as it is widespread in other bird species (Weise \& Meyer, 1979; Greenwood \& Harvey, 1982; Ferrer

517 1993; Cooper et al., 2008; Whitfield et al., 2009). Juveniles tend to disperse (as recently 518 suggested for Dupont's Lark, Pérez-Granados et al., 2021), moving long distance across non519 habitat areas and to settle new populations with few initial individuals (Harrison et al., 1989). In 
520 the case of the Dupont's Lark, juvenile movements of $5 \mathrm{~km}$ are very likely; those comprising 5-

$52120 \mathrm{~km}$ of high probability; 20-100 km of low probability; over $100 \mathrm{~km}$ of very low probability.

522 This last distance would be rare events of sporadic long-distance movements (Supplemental

523 Table S1).

524 The importance of stepping stones facilitating movements between habitat fragments has

525 been reported in different ecosystems and species. Uezu et al. (2008) showed in the bird

526 community of the Brazilian Atlantic forest that the efficiency of stepping stones is species-

527 dependent and related to matrix resistance. Baum et al. (2004) also highlighted the importance of

528 the surrounding matrix for the effectiveness of stepping stones in plants. Saura et al. (2014)

529 found that the loss of stepping stones can cause a sharp decline in the potential movement

530 distance in bird species, which are not compensated for other factors (e.g., source population

531 size). Stepping stones could also have some negative effects, as Kramer-Schadt et al. (2011)

532 found in a mammal species, with a trade-off related to stepping stone size and location.

533 The situation of Dupont's Lark shows dramatic declines and ongoing habitat

534 fragmentation and contraction (Gómez-Catasús et al., 2018a; García-Antón et al., 2019),

535 urgently suggests that immediate management of the species and habitat are necessary. In the

536 current context of land intensification and rural abandonment, Dupont's Lark habitat has a finite

537 lifetime. As smaller patches disappear, the larger ones, which presently hold the majority of the

538 population, will become more vulnerable due to the loss of linked habitat and the decrease of

539 connectivity. Besides, several aspects of this species remain partially unknown and are crucial

540 for its conservation, as dispersal mechanisms, reproductive biology or genetics, which are

541 needed for a detailed evaluation of the connectivity and population viability of Dupont's Lark.

542

543 Conclusions

544 Conservation and management of the Dupont's Lark in Spain is urgent, and here we list

545 the most important areas to carry that out. Habitat loss and fragmentation must be urgently

546 stopped in Dupont's Lark subpopulations and stepping stones. This is mainly being produced by

547 ploughing, windfarms and afforestation. Additionally, the increase of habitat quality both in

548 short (restoration measures) and long terms (extensive grazing) is desirable for the species

549 conservation. Isolation of the southern range is extreme and, due to the recent subpopulation

550 extinctions, we speculate a near-future distribution restricted to the current metapopulation core.

551 Research on movements, especially on breeding dispersal, would help clarifying movement

552 patterns in the metapopulation and establishing ecological corridors to increase connectivity.

553 Acknowledgements

554 We wish to acknowledge to Francisco Quico Suárez, who led the Dupont's Lark research group

555 until his early death in 2010. Many people collected data in the field; we especially wish to

556 thank: A. Agirre, R. Aymí, M. Calero, E. Carriles, J. T. García, I. Hervás, J. H. Justribó, E. G. de

557 la Morena, J. J. Oñate and J. Viñuela. Data used in this paper come from different projects, in

558 particular the II National Census (2004-2006), granted by the Spanish Ministry of Environment;

559 the Dupont's Lark Monitoring Program in Medinaceli Region, funded by Fundación Patrimonio 
560 Natural de Castilla y León, and the projects "Criteria for the management and conservation of the

561 Spanish population of Dupont's Lark, supported by Fundación Biodiversidad, of the Ministry of

562 Agriculture, Food and Environment; LIFE Ricotí (LIFE15-NAT-ES-000802), supported by the

563 European Commission; and BBVA-Dron Ricotí, funded by the BBVA Foundation. All birds

564 were captured and processed following the Wild Birds Ringing Manual and under the

565 correspondent official licenses. This is a contribution to the Excellence Network Remedinal

566 3CM (S2013/MAE-2719), supported by Comunidad de Madrid.

\section{References}

568 Balfagón J, Carrion Piquer J (2021). https://ebird.org/checklist/S79212429

569 Baranyi G, Saura S, Jordán, F (2011) Contribution of Habitat Patches to Network Connectivity:

570 Redundancy and Uniqueness of Topological Indices. Ecological Indicators - ECOL INDIC. 11.

571 1301-1310. 10.1016/j.ecolind.2011.02.003.

572 Baum KA, Haynes KJ, Dillemuth FP and Cronin JT (2004) The matrix enhances the

573 effectiveness of corridors and stepping stones. Ecology, 85: 2671-

574 2676. https://doi.org/10.1890/04-0500

575 Bodin Ö, Saura S (2010) Ranking Individual Habitat Patches as Connectivity Providers:

576 Integrating Network Analysis and Patch Removal Experiments. Ecological Modelling.

577 221:2393-2405

578 Bota G, Giralt D, Guixé D (2016) La Alondra Ricotí en Cataluña: evolución histórica de una

579 población en el límite del área de distribución. II Meeting of the Dupont's Lark Experts Group,

580 Madrid

581 Calabrese J, Fagan W (2004) A Comparison-Shopper's Guide to Connectivity Metrics. Frontiers

582 in Ecology and The Environment 2(10):529-536

583 Cooper CB, Daniels SJ, Walters JR (2008) Can we improve estimates of juvenile dispersal

584 distance and survival. Ecology 89: 3349-3361.

585 Cramp S, Simmons KEL (1980) The Birds of the Western Palearctic. Vol. II, Oxford University

586 Press, Oxford

587 Crooks KR, Sanjayan M (2006) Connectivity Conservation. Cambridge University Press

588 De Juana E, Suárez F (2020) Dupont's Lark (Chersophilus duponti). In: del Hoyo J, Elliott A,

589 Sargatal J, Christie DA, de Juana E (eds) Handbook of the Birds of the World Alive. Lynx

590 Edicions, Barcelona (retrieved from https://www.hbw.com/node/57638)

591 Dies B, Alcocer T, Llorens V, Piera M, Marín P, Ruiz P (2010) Alondra Ricotí: una primera cita

592 para l'Albufera. http://www.birdingalbufera.es/?q = es/node/496

593 Ferrer M (1993) Juvenile dispersal behaviour and natal philopatry of a long-lived raptor, the

594 Spanish Imperial Eagle Aquila adalberti. Ibis 135: 132-138.

595 Foltête J, Savary P, Clauzel C, Bourgeois M, Girardet X, Saharoui Y, Vuidel G, Garnier S

596 (2020) Coupling landscape graph modeling and biological data: a review. Landscape Ecol.

597 https://doi.org/10.1007/s10980-020-00998-7 
598 García-Antón A, Garza V, Traba J (2015) Dispersión de más de $30 \mathrm{Km}$ en un macho de primer 599 año de Alondra Ricotí (Chersophilus duponti) en el Sistema Ibérico. I Meeting of the Dupont's 600 Lark Experts Group, Granada, Spain

601 García-Antón A, Garza V, Traba J (2018) Climate, isolation and intraspecific competition affect

602 morphological traits in an endangered steppe bird, the Dupont's Lark Chersophilus duponti. Bird 603 Study 65(3):373-384

604 García-Antón A, Garza V, Hernández Justribó J, Traba J (2019) Factors affecting Dupont's lark 605 distribution and range regression in Spain. PLOS ONE. 14. e0211549.

606 10.1371/journal.pone.0211549.

607 García-Antón A, Garza V, Traba J (2021) Viability analysis of the European population of the 608 endangered Dupont's Lark Chersophilus duponti. Under review.

609 García JT, Suárez F, Garza V, Calero-Riestra M, Hernández J, Pérez-Tris J (2008) Genetic and 610 phenotypic variation among geographically isolated populations of the globally threatened

611 Dupont's Lark Chersophilus duponti. Mol. Phylogenet. Evol. 46:237-251

612 García T, Requena C (2015) Alondra Ricotí en las Salinas de Marchamalo.

613 https://pachequerobirder.blogspot.com/2015/08/alondra-ricoti-en-las-salinas-de.html

614 Garza V, Suárez F (1990) Distribución, población y selección de hábitat de la Alondra de

615 Dupont (Chersophilus duponti) en la península ibérica. Ardeola 37:3-12

616 Garza V, Traba J, Suárez F (2003) Is the European population of Dupont's Lark

617 Chersophilus duponti adequately estimated? Bird Study 50:309-311

618 Garza V, Suárez F, Tella JL (2004) Alondra de Dupont, Chersophilus duponti. In: Madroño A, 619 González C, Atienza JC (eds). Libro Rojo de las Aves de España. Madrid: Dirección General 620 para la Biodiversidad-SEO/BirdLife pp 309-312

621 Garza V, Suárez F, Herranz J, Traba J, García de la Morena EL, Morales MB, González R,

622 Castañeda M (2005) Home range, territoriality and habitat selection by the Dupont's Lark

623 Chersophilus duponti during the breeding and postbreeding periods. Ardeola 52:133-146

624 Garza V, García JT, Calero M, Suárez F (2006) Tendencias y situación actual de las poblaciones 625 de la Alondra Ricotí Chersophilus duponti en Andalucía, España. Ecología 20:85-96

626 Gómez-Catasús J, Pérez-Granados C, Diego A, Bota G, Giralt D, López-Iborra G, Serrano D,

627 Traba J (2018a). European population trends and current conservation status of an endangered

628 steppe-bird species: The Dupont's Lark Chersophilus duponti. PeerJ 6:e5627

629 https://doi.org/10.7717/peerj.5627

630 Gómez-Catasús J, Garza V, Traba J (2018b) Effect of wind farms on small passerine birds:

631 occurrence, abundance and population trends of a threatened species, the Dupont's Lark

632 Chersophilus duponti. Journal of Applied Ecology 55(4):2033-2042.

633 https://doi.org/10.1111/1365-2664.13107

634 Gómez-Catasús J, Garza V, Morales M.B. et al. Hierarchical habitat-use by an endangered

635 steppe bird in fragmented landscapes is associated with large connected patches and high food 636 availability. Sci Rep 9, 19010 (2019). https://doi.org/10.1038/s41598-019-55467-2 
637 Grafius DR, Corstanje R, Siriwardena GM, Plummer KE, Harris JA (2017) A bird's eye view:

638 using circuit theory to study urban landscape connectivity for birds. Landscape Ecol 32, 17716391787.

640 Greenwood PJ, Harvey PH (1982) The natal and breeding dispersal of birds. Ann. Rev. Ecol.

641 Syst. 13: 1-21.

642 Hanski I (1998) Metapopulation dynamics. Nature 396:41-49

643 Hanski I (1999a) Metapopulation ecology. Oxford University Press

644 Hanski I (1999b) Habitat connectivity, habitat continuity, and metapopulations in dynamic

645 landscapes. Oikos 87:209-219

646 Hanski I, Gaggiotti O (2004) Ecology, Genetics and Evolution of Metapopulations. Academic

647 Press

648 Harrison S (1989) Long-Distance Dispersal and Colonization in the Bay Checkerspot Butterfly, 649 Euphydryas Editha Bayensis. Ecology 70: 1236-1243

650 Íñigo A, Garza V, Tella JL, Laiolo P, Suárez F, Barov B (2008) Action Plan for the Dupont's

651 Lark Chersophilus duponti in the European Union. SEO/Birdlife - BirdLife International -

652 Comisión Europea

653 Kramer-Schadt S, Kaiser T, Frank K, Wiegand T (2011) Analyzing the effect of stepping stones 654 on target patch colonisation in structured landscapes for Eurasian lynx. Landscape Ecol 26, 501-

655 513. https://doi.org/10.1007/s10980-011-9576-4

656 Laiolo P, Vögeli M, Serrano D, Tella JL (2008) Song Diversity Predicts the Viability of

657 Fragmented Bird Populations. PLoS One. https://doi.org/10.1371/journal.pone.0001822

658 Laiolo P, Vögeli M, Serrano D, Tella JL (2007) Testing acoustic versus physical marking: two

659 complementary methods for individual-based monitoring of elusive species. Journal of Avian

660 Biology. https://doi.org/10.1111/j.2007.0908-8857.04006.x

661 Laiolo P (2008) Characterizing the spatial structure of songbird cultures. Ecological

662 Applications. https://doi.org/10.1890/07-1433.1

663 Laiolo P, Vögeli M, Serrano D, Tella JL (2008) Song Diversity Predicts the Viability of

664 Fragmented Bird Populations. PLoS One. https://doi.org/10.1371/journal.pone.0001822

665 Levins R (1969) Some demographic and genetic consequences of environmental heterogeneity

666 for biological control. Bulletin of the Entomological Society of America.

667 https://doi.org/10.1093/besa/15.3.237

668 Levins R (1970) Extinction. In: Gerstenhaber M (ed) Lecture notes on mathematics in the life

669 sciences. Annals of New York Academy of Sciences Vol. 231, pp 75-107

670 Loehle C (2007) Effect of ephemeral stepping stones on metapopulations on fragmented

671 landscapes. Ecological Complexity. https://doi.org/10.1016/j.ecocom.2007.02.015

672 MacArthur RH, Wilson EO (2001) The Theory of Island Biogeography. Princeton University

673 Press

674 Losos JB, Ricklefs RE (2009) The Theory of Island Biogeography Revisited. Princeton

675 University Press. 
676 Martín-Vivaldi M, Martín JM, Archila F, López E, de Manuel LC (1999) Caracterización de una 677 nueva población reproductora de Alondra de Dupont (Chersophilus duponti) (Passeriformes,

678 Alaudidae) en el Sureste ibérico. Zoologica Baetica 10:185-192.

679 Mazaris AD, Papanikolaou AD, Barbet-Massin M, Kallimanis AS, Jiguet F, Schmeller DS,

680 Pantis JD (2013) Evaluating the Connectivity of a Protected Areas' Network under the Prism of

681 Global Change: The Efficiency of the European Natura 2000 Network for Four Birds of Prey.

682 PLoS One. https://doi.org/10.1371/journal.pone.0059640

683 Méndez M, Tella JL, Godoy JA (2011) Restricted gene flow and genetic drift in recently

684 fragmented populations of an endangered steppe bird. Biological Conservation.

685 https://doi.org/10.1016/j.biocon.2011.07.011

686 Méndez M, Vögeli M, Tella JL, Godoy JA (2014) Joint effects of population size and isolation

687 on genetic erosion in fragmented populations: finding fragmentation thresholds for management.

688 Evol Appl 7(4):506-18

689 Nogués-Bravo D, Agirre A (2006) Patrón y modelos de distribución espacial de la alondra ricotí

690 Chersophilus duponti durante el periodo reproductor en el LIC de Ablitas (Navarra). Ardeola

$691 \quad 53: 55-68$

692 Pascual-Hortal L, Saura S (2007) A new habitat availability index to integrate connectivity in

693 landscape conservation planning: Comparison with existing indices and application to a case

694 study. Landscape and Urban Planning. https://doi.org/10.1016/j.landurbplan.2007.03.005

695 Pascual-Hortal L, Saura S (2006) Comparison and development of new graph-based landscape

696 connectivity indices: towards the priorization of habitat patches and corridors for conservation.

697 Landscape Ecology 21:959-967

698 Peco B, Carmona CP, de Pablos I, Azcárate FM (2012) Effects of grazing abandonment on

699 functional and taxonomic diversity of Mediterranean grasslands. Agriculture, Ecosystems \&

700 Environment 152: 27-32.

701 Pereira J, Saura S, Jordán F (2017) Single-node vs. multi-node centrality in landscape graph

702 analysis: key habitat patches and their protection for 20 bird species in NE Spain. Methods in

703 Ecology and Evolution. https://doi.org/10.1111/2041-210X.12783

704 Pérez-Granados C, López-Iborra GM (2013) Census of breeding birds and population trends of

705 the Dupont's Lark Chersophilus duponti in Eastern Spain. Ardeola 60(1):143-150

706 Pérez-Granados C, López-Iborra GM (2015) Baja dispersión adulta y baja tasa de recaptura

707 juvenil de la alondra ricotí (Chersophilus duponti) en el Rincón de Ademuz (Valencia). XX

708 Iberian Ringing Congress

709 Pérez-Granados C, López-Iborra GM, Garza V (2017) Breeding biology of the endangered

710 Dupont's Lark Chersophilus duponti in two separate Spanish shrub-steppes

711 Bird Study 64(3):328-338

712 Pérez-Granados C, Sáez-Gómez C, López-Iborra GM (2021). Breeding dispersal movements of

713 Dupont's Lark Chersophilus duponti in fragmented landscape. Bird Conservation

714 International, 1-11. doi:10.1017/S095927092100006X

715 QGIS.org, 2021. QGIS Geographic Information System. QGIS Association. 
716 Reverter M, Gómez-Catasús J, Barrero A, Pérez-Granados C, Bustillo-de la Rosa D, Traba J

717 (2019). Interactions in shrub-steppes: implications for the maintenance of a threatened bird.

718 Ecosistemas, 28(2):69-77

719 Ricketts TH, Gretchen CD, Ehrlich PR, Fay JP (2002) Countryside Biogeography of Moths in a

720 Fragmented Landscape: Biodiversity in Native and Agricultural Habitats. Conservation Biology.

721 https://doi.org/10.1046/j.1523-1739.2001.015002378.x

722 Rolstad J (2008). Consequences of forest fragmentation for the dynamics of bird populations:

723 conceptual issues and the evidence. Biological Journal of the Linnean Society 42:149-163

724 Saura S, Torne J (2009) Conefor Sensinode 2.2: A software package for quantifying the

725 importance of habitat patches for landscape connectivity. Environmental Modelling \& Software.

726 24(1)135-139

727 Saura S, Rubio L (2010) A common currency for the different ways in which patches and links

728

729 can contribute to habitat availability and connectivity in the landscape. Ecography. https://doi.org/10.1111/j.1600-0587.2009.05760.x

730 Saura S, Estreguilb C, Mouton C, Rodríguez-Freireb M (2011) Network analysis to assess

731 landscape connectivity trends: Application to European forests (1990-2000). Ecological

732 Indicators. https://doi.org/10.1016/j.ecolind.2010.06.011

733 Saura S, Bodin Ö and Fortin MJ (2014) EDITOR'S CHOICE: Stepping stones are crucial for

734 species' long-distance dispersal and range expansion through habitat networks. J Appl Ecol, 51:

735 171-182. https://doi.org/10.1111/1365-2664.12179

736 Seoane J, Justribó JH, García F, Retamar J, Rabadan C, Atienza JC. Habitat-suitability modelling 737 to assess the effects of land-use changes on Dupont's Lark Chersophilus duponti: a case study in 738 the Layna Important Bird Area. Biological Conservation 8:241-252

739 Serrano D, Margalida A, Pérez-García JM, Juste J, Traba J, Valera F, Carrete M, Aihartza J, Real

740 J, Mañosa S, Flaquer C, Garin I, Morales MB, Alcalde JT, Arroyo B, Sánchez-Zapata JA,

741 Blanco G, Negro JJ, Tella JL, Ibañez C, Tellería JL, Hiraldo F, Donázar JA. Renewables in

742 Spain threaten biodiversity. Science. 2020 Dec 11;370(6522):1282-1283. doi:

743 10.1126/science.abf6509. PMID: 33303607.

744 Shake CS, Moorman CE, Riddle JD, Burchell MR (2012) Influence of Patch Size and Shape on

745 Occupancy by Shrubland Birds. The Condor 114(2):268-278

746 Suárez F, Garza (1989) La invernada de la Alondra de Dupont, Chersophilus duponti, en la

747 Península Ibérica. Ardeola 36:107-110

748 Suárez F, Garcia JT, Sampietro FJ, Garza V (2006) The non-breeding distribution of Dupont's

749 Lark Chersophilus duponti in Spain. Bird Conservation International 16:317-323.

750 Suárez F (2010) La Alondra Ricotí (Chersophilus duponti). Dirección General Para La

751 Biodiversidad. Ministerio de Medio Ambiente y Medio Rural y Marino, Madrid

752 Suárez F and Carriles E (2010) Análisis de viabilidad poblacional. In: Suárez F (ed.) La alondra

753 ricotí (Chersophilus duponti), pp. 319-326. Dirección General para la Biodiversidad. Ministerio

754 de Medio Ambiente y Medio Rural y Marino. Madrid (2010). 
755 Traba J, Garza V, García-Antón A, Gómez-Catasús J, Zurdo J, Pérez-Granados C, Morales MB,

756 Oñate JJ, Herranz J, Malo J (2019) Criterios para la gestión y conservación de la población

757 española de alondra ricotí Chersophilus duponti. Fundación Biodiversidad, Ministerio de

758 Agricultura, Alimentación y Medio Ambiente. Madrid

759 Traba J, García de la Morena EL and Garza V (2011) Análisis de Viabilidad de Poblaciones

760 como herramienta para el diseño de Parques Eólicos. El caso de las poblaciones de alondra ricotí

761 (Chersophilus duponti) del sur de Soria. I Congreso Ibérico sobre Energía Eólica y Conservación

762 de Fauna. Jerez de la Frontera, Cádiz

763 Uezu A, Beyer DD and Metzger JP (2008) Can agroforest woodlots work as stepping stones for birds in

764 the Atlantic forest region?. Biodivers Conserv 17, 1907-1922. https://doi.org/10.1007/s10531-008-9329-0

765 Vergara PM, Pérez-Hernández CG, Hahn IJ, Soto GE (2013) Deforestation in central Chile

766 causes a rapid decline in landscape connectivity for a forest specialist bird species. Ecol

767 Res 28:481-492

768 Visconti P, Elkin C (2009). Using connectivity metrics in conservation planning - When does

769 habitat quality matter? Diversity and Distributions. https://doi.org/10.1111/j.1472-

$770 \quad 4642.2009 .00564 . x$

771 Vögeli M, Laiolo P, Serrano D, Tella JL (2008) Who are we sampling? Apparent survival differs

772 between methods in a secretive species. Oikos. https://doi.org/10.1111/j.1600-

773 0706.2008.17225.x

774 Vögeli M, Serrano D, Pacios S, Tella JL (2010) The relative importance of patch habitat quality

775 and landscape attributes on a declining steppe-bird metapopulation. Biological Conservation.

776 https://doi.org/10.1016/j.biocon.2009.12.040

777 Vögeli M, Laiolo P, Serrano D, Tella JL (2011) Predation of experimental nests is linked to local

778 population dynamics in a fragmented bird population. Biology Letters 7:954-957

779 Watling J, Nowakowski A, Donnelly M, Orrock J (2011) Meta-analysis reveals the importance

780 of matrix composition for animals in fragmented habitat. Global Ecology and Biogeography

781 20(2):209-217

782 Weise CM, Meyer JR (1979) Juvenile Dispersal and Development of Site-Fidelity in the Black-

783 Capped Chickadee. The Auk, 96(1): 40-55.

784 Whitfield DP, Duffy K, McLeod DRA, Evans RJ, MacLennan AM, Reid R, Sexton D, Wilson

785 JD, Douse A (2009) Juvenile Dispersal of White-Tailed Eagles in Western Scotland. Journal of

786 Raptor Research 43(2): 110-120.

787 Whittaker RJ, Fernandez-Palacios JM (2007). Island Biogeography: Ecology, Evolution, and

788 Conservation. Oxford University Press. 


\section{Figure 1}

Definition of localities, subpopulations and populations.

Localities are demarcated by a $0.5 \mathrm{~km}$ buffer (red), so that observations separated by a distance $>1 \mathrm{~km}$ belong to different localities. Subpopulations are delimited by a buffer of 2.5 $\mathrm{km}$ (blue) and a distance of $5 \mathrm{~km}$ between observations. Finally, observations distanced $>20$ $\mathrm{km}$ belong to different populations (buffer of $10 \mathrm{~km}$, black). Red dots indicate Dupont's lark observations and green polygons, the adequate habitat within subpopulations.

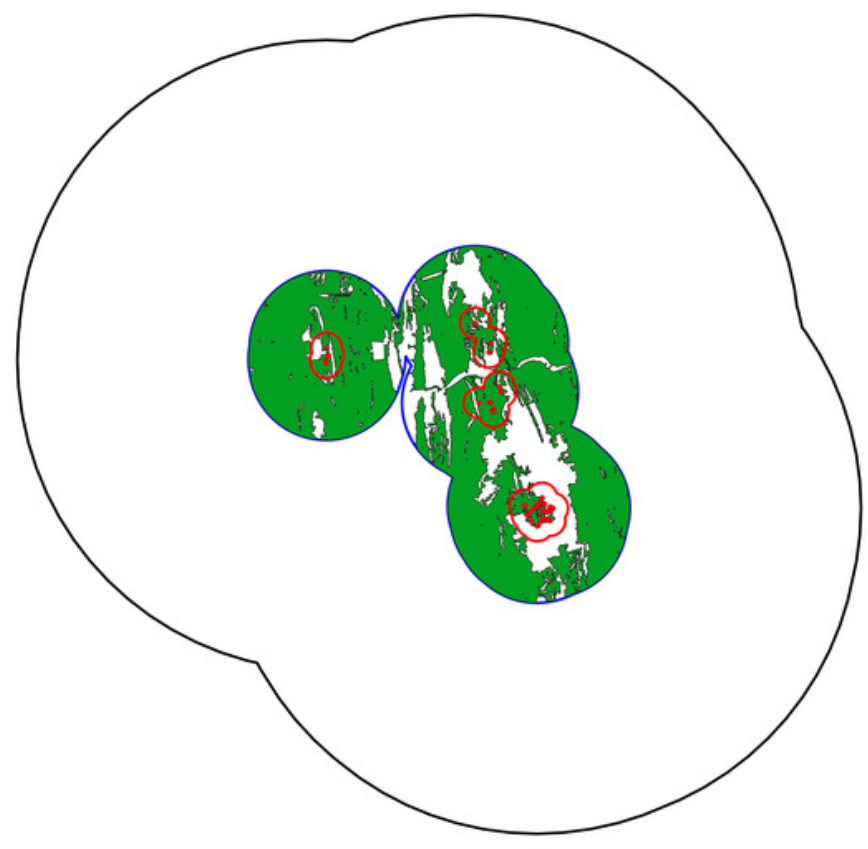

$\because$ Dupont's lark observations

Species habitat

$0.5 \mathrm{~km}$ buffer — Localities

$2.5 \mathrm{~km}$ buffer — Subpopulations

$10 \mathrm{~km}$ buffer — Populations

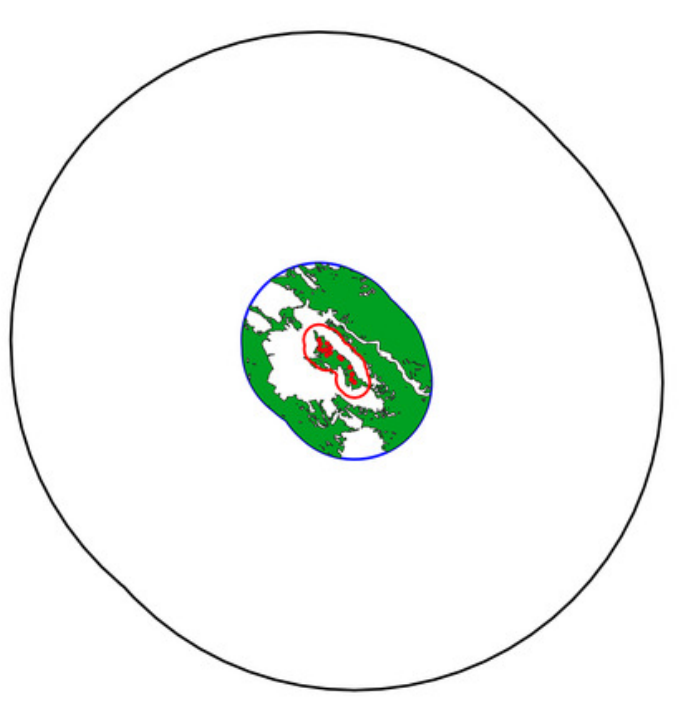


Figure 2

Map of current populations, subpopulations and stepping stones of the Iberian metapopulation of Dupont's lark.

Black contours represent populations $(n=24)$, green polygons are subpopulations $(n=100)$ and black dots indicate stepping stones $(n=294)$. Red crosses represent the 23

subpopulations of recent extinction (post-2000). See detailed cartography in Supplemental Data S1.

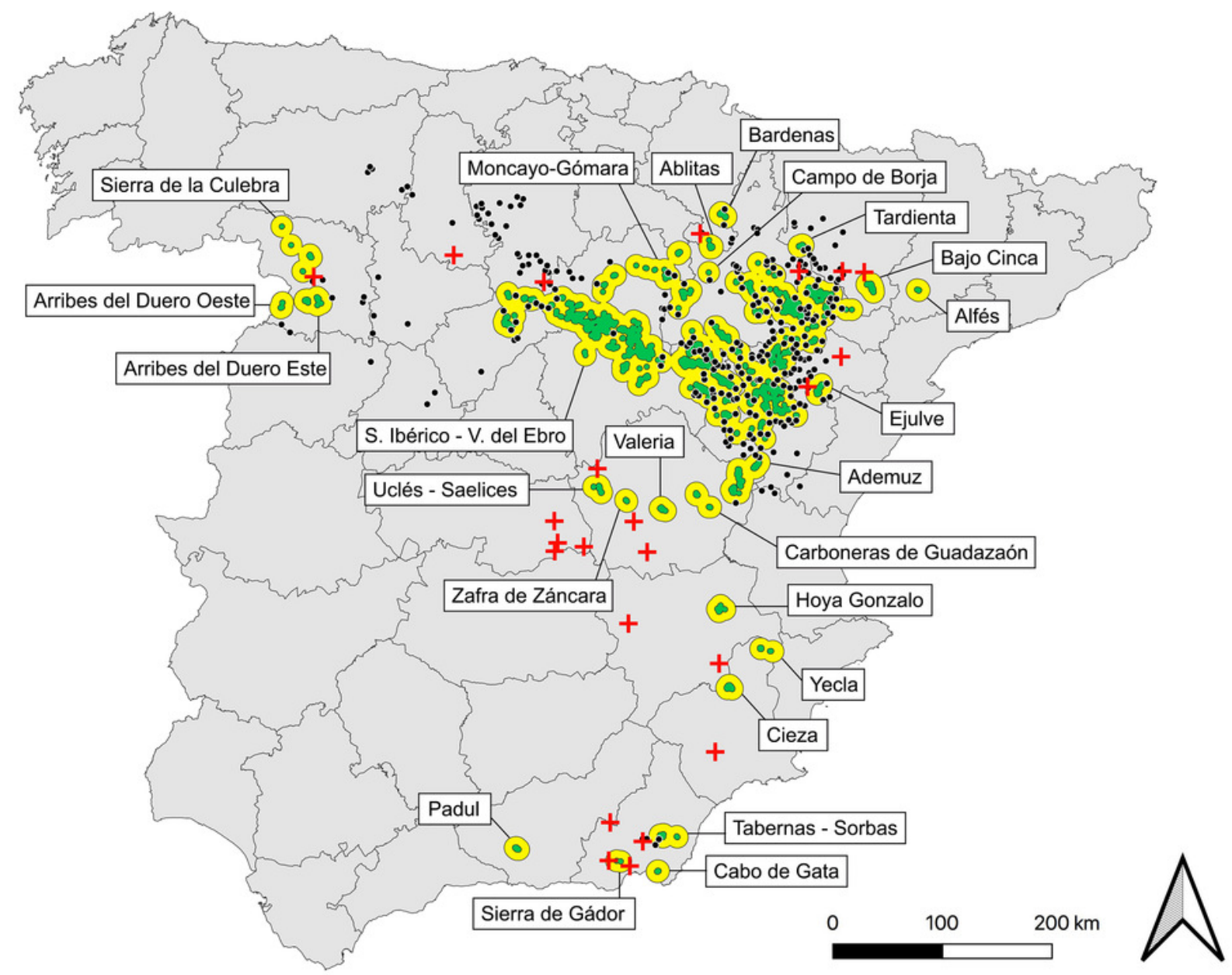




\section{Figure 3}

Map of node importances in the Iberian metapopulation of Dupont's lark.

Nodes classified by general importance index (dPC). The core of the distribution, focused in the Iberian Range - Ebro Valley population, gathers the most important nodes. Here we show scenario 5 (movements of $20 \mathrm{~km}$ and presence of stepping stones). Maps for all possible scenarios are included in Supplemental Data S2.

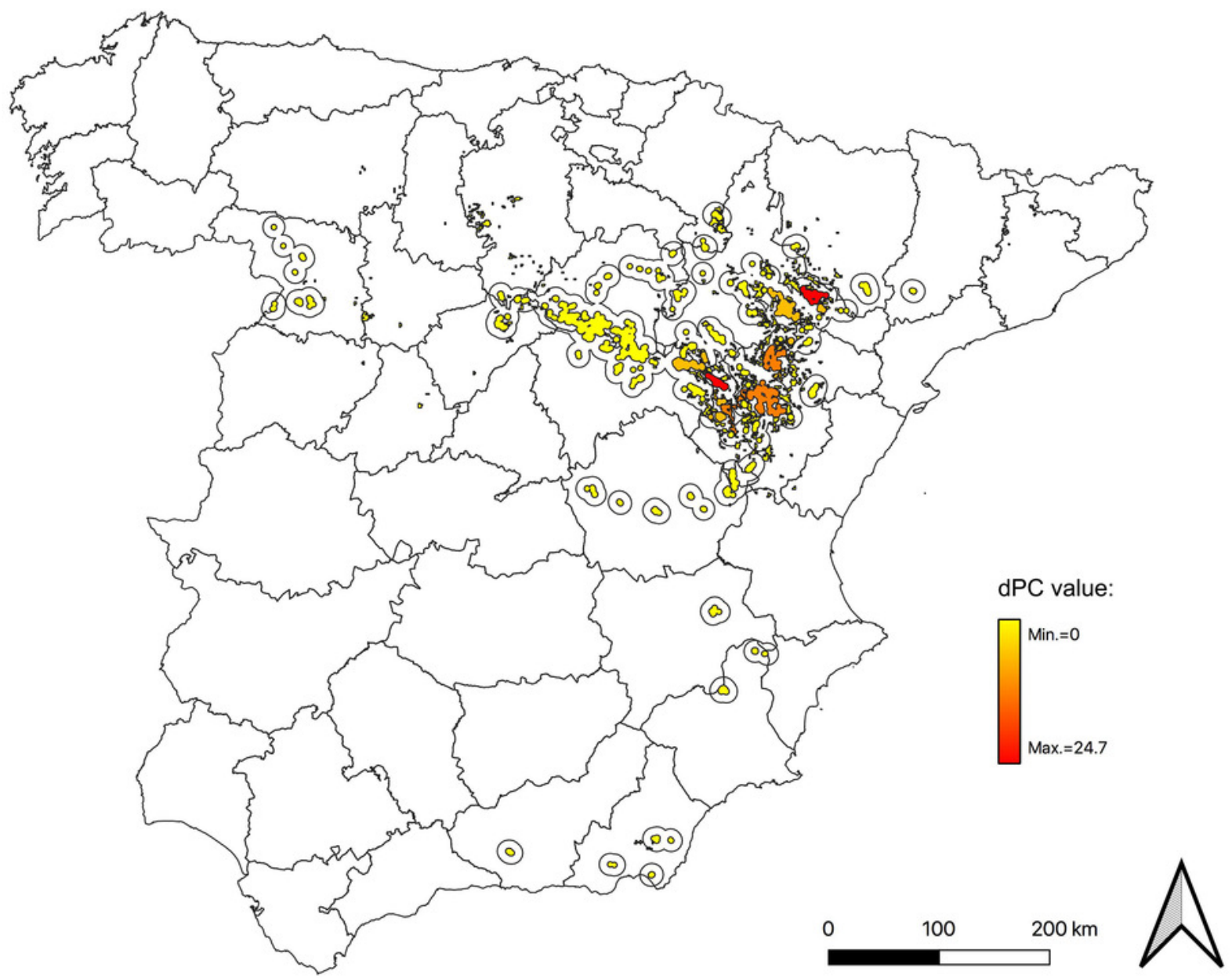




\section{Figure 4}

Probability of connection of Dupont's lark metapopulation under the different scenarios evaluated.

Effect of the distance (movements of 5, 20 and $100 \mathrm{~km}$ ) and the presence/absence of stepping stones in the probability of connection among Dupont's lark subpopulations. See Supplemental Data S2 for the complete matrix of probability of connection for node pairs. 

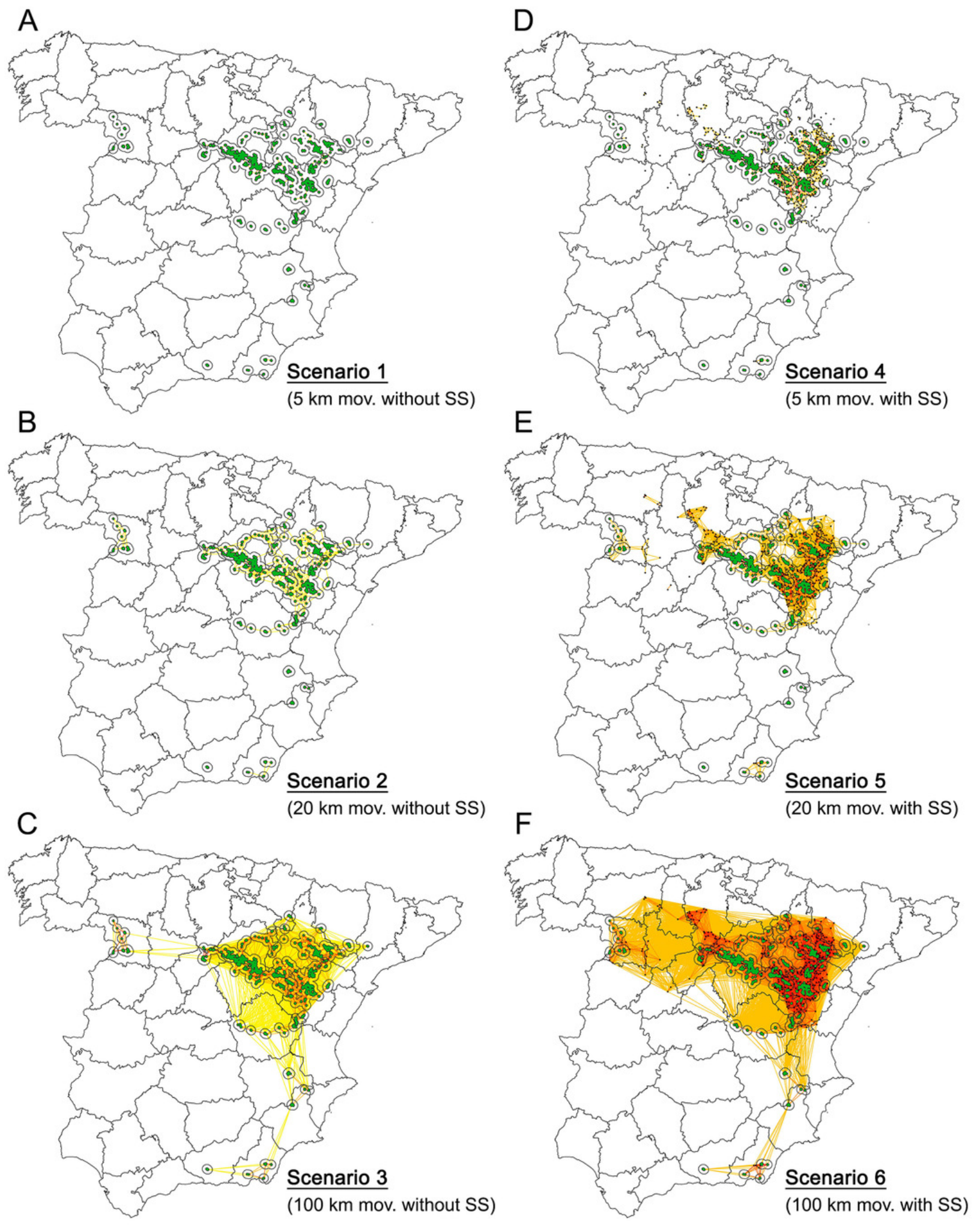

Probability of connection: $0.001-20 \%$ $20-40 \%$ $-40-60 \%$ $-60-80 \%$ $-80-100 \% \quad 0 \quad 100 \quad 200 \mathrm{~km}$ 


\section{Table $\mathbf{1}$ (on next page)}

Summary of the 10 most important nodes for intra-patch connectivity $\left(\mathrm{dPC}_{\text {intra }}\right)$.

$\mathrm{dPC}_{\text {intra }}$ makes reference to the internal importance of each node and it is independent on spatial position. Thus, the ranking is the same for the different movement thresholds. See the complete list in Supplemental Data S2. 


\begin{tabular}{|c|c|c|c|}
\hline & & $\begin{array}{c}\text { Without stepping stones } \\
\quad \text { (scenario } 1,2,3 \text { ) }\end{array}$ & $\begin{array}{l}\text { With stepping stones } \\
\text { (scenario } 4,5,6)\end{array}$ \\
\hline Name & Prov. & $\mathrm{dPC}_{\text {intra }}$ & $\mathrm{dPC}_{\text {intra }}$ \\
\hline Monegros & Zaragoza & 33.34 & 4.49 \\
\hline Blancas & Teruel & 17.77 & 2.39 \\
\hline Torralba de los Frailes & Teruel & 4.16 & 0.56 \\
\hline Bardenas & Navarra & 2.64 & 0.36 \\
\hline Lécera & Zaragoza & 2.10 & 0.28 \\
\hline Pinilla del Campo & Soria & 1.49 & 0.20 \\
\hline Campo Romanos & Zaragoza & 1.47 & 0.20 \\
\hline Paramera de Molina & Guadalajara & 1.39 & 0.19 \\
\hline Orihuela del Tremedal & Teruel & 1.25 & 0.17 \\
\hline Gelsa & Zaragoza & 1.16 & 0.16 \\
\hline
\end{tabular}




\section{Table 2 (on next page)}

Summary of the 10 most important nodes for flow generation in the network $\left(\mathrm{dPC}_{\text {fux }}\right)$.

Stepping stones are indicated as 'SS'. See the complete list in Supplemental Data S2. 


\begin{tabular}{|c|c|c|c|c|c|}
\hline \multicolumn{3}{|c|}{ Scenario 1 (5 km mov. without SS) } & \multicolumn{3}{|c|}{ Scenario 4 (5 km mov. with SS) } \\
\hline Name & Prov. & $\mathrm{dPC}_{\text {flux }}$ & Name & Prov. & $\mathrm{dPC}_{\text {flux }}$ \\
\hline Monegros & Zaragoza & 7.64 & Blancas & Teruel & 14.77 \\
\hline Gelsa & Zaragoza & 7.06 & Monegros & Zaragoza & 14.03 \\
\hline Torralba de los Frailes & Teruel & 5.82 & Torralba de los Frailes & Teruel & 7.64 \\
\hline Paramera de Molina & Guadalajara & 5.33 & Paramera de Molina & Guadalajara & 6.11 \\
\hline Blancas & Teruel & 3.52 & Gelsa & Zaragoza & 4.79 \\
\hline Alforque & Zaragoza & 1.05 & Orihuela del Tremedal & Teruel & 4.23 \\
\hline Pinilla del Campo & Soria & 1.02 & (E) Monegrillo 2 & Zaragoza & 3.62 \\
\hline Milmarcos-Llumes & Guadalajara & 1.02 & Pozondón & Teruel & 3.11 \\
\hline Pozalmuro & Soria & 0.89 & (E) Alfajarín 1 & Zaragoza & 2.69 \\
\hline Cenegro & Soria & 0.82 & (E) Torralba de los Sisones & Teruel & 2.58 \\
\hline \multicolumn{3}{|c|}{ Scenario $2(20 \mathrm{~km}$ mov. without $\mathrm{SS})$} & \multicolumn{3}{|c|}{ Scenario 5 (20 km mov. with SS) } \\
\hline Name & Prov. & $\mathrm{dPC}_{\text {flux }}$ & Name & Prov. & $\mathrm{dPC}_{\text {flux }}$ \\
\hline Blancas & Teruel & 15.14 & Blancas & Teruel & 16.33 \\
\hline Monegros & Zaragoza & 13.48 & Monegros & Zaragoza & 13.50 \\
\hline Torralba de los Frailes & Teruel & 11.07 & Torralba de los Frailes & Teruel & 8.08 \\
\hline Paramera de Molina & Guadalajara & 7.89 & Paramera de Molina & Guadalajara & 5.25 \\
\hline Gelsa & Zaragoza & 7.81 & Orihuela del Tremedal & Teruel & 5.07 \\
\hline Belchite & Zaragoza & 3.34 & Lécera & Zaragoza & 5.00 \\
\hline La Torresaviñán & Guadalajara & 2.82 & Gelsa & Zaragoza & 3.74 \\
\hline Lécera & Zaragoza & 2.81 & Belchite & Zaragoza & 3.48 \\
\hline Cenegro & Soria & 2.61 & Pozondón & Teruel & 3.38 \\
\hline Alforque & Zaragoza & 2.54 & Celadas Este & Teruel & 2.51 \\
\hline \multicolumn{3}{|c|}{ Scenario $3(100 \mathrm{~km}$ mov. without SS) } & \multicolumn{3}{|c|}{ Scenario $6(100 \mathrm{~km}$ mov. with SS) } \\
\hline Name & Prov. & $\mathrm{dPC}_{\text {flux }}$ & Name & Prov. & $\mathrm{dPC}_{\text {flux }}$ \\
\hline Blancas & Teruel & 20.86 & Monegros & Zaragoza & 15.01 \\
\hline Monegros & Zaragoza & 19.70 & Blancas & Teruel & 12.94 \\
\hline Torralba de los Frailes & Teruel & 11.30 & Torralba de los Frailes & Teruel & 6.42 \\
\hline Lécera & Zaragoza & 7.22 & Lécera & Zaragoza & 4.74 \\
\hline Paramera de Molina & Guadalajara & 6.94 & Paramera de Molina & Guadalajara & 3.84 \\
\hline Campo Romanos & Zaragoza & 5.49 & Orihuela del Tremedal & Teruel & 3.70 \\
\hline Gelsa & Zaragoza & 5.35 & Belchite & Zaragoza & 3.44 \\
\hline Orihuela del Tremedal & Teruel & 5.21 & Campo Romanos & Zaragoza & 3.43 \\
\hline Belchite & Zaragoza & 5.09 & Gelsa & Zaragoza & 3.19 \\
\hline La Torresaviñán & Guadalajara & 4.85 & La Torresaviñán & Guadalajara & 2.48 \\
\hline
\end{tabular}




\section{Table 3(on next page)}

Summary of the 10 most important nodes for connectivity maintenance $\left(\mathrm{dPC}_{\text {connector }}\right)$.

Stepping stones are indicated as 'SS'. See the complete list in Supplemental Data S2. 


\begin{tabular}{|c|c|c|c|c|c|}
\hline \multicolumn{3}{|c|}{ Scenario 1 (5 km mov. without SS) } & \multicolumn{3}{|c|}{ Scenario 4 (5 km mov. with SS) } \\
\hline Name & Prov. & $\mathrm{dPC}_{\text {conn }}$ & Name & Prov. & $\mathrm{dPC}_{\text {conn }}$ \\
\hline Paramera de Molina & Guadalajara & 2.38 & (SS) Alba & Teruel & 9.30 \\
\hline Layna & Soria & 0.87 & Villar del Salz & Teruel & 6.89 \\
\hline Altos de Barahona & Soria & 0.83 & (SS) Rubielos de la Cérida & Teruel & 6.70 \\
\hline Gelsa & Zaragoza & 0.78 & Paramera de Molina & Guadalajara & 5.70 \\
\hline Pozalmuro & Soria & 0.11 & (SS) Ojos Negros 1 & Teruel & 4.85 \\
\hline Aldealpozo & Soria & 0.06 & (SS) Cuerlas 1 & Zaragoza & 4.68 \\
\hline Cueva de la Hoz & Guadalajara & 0.04 & Blancas & Teruel & 3.84 \\
\hline Altiplano de Teruel & Teruel & 0.02 & Pozondón & Teruel & 3.54 \\
\hline Alforque & Zaragoza & 0.02 & (SS) Celadas & Teruel & 2.98 \\
\hline Conquezuela & Soria & 0.01 & Monegros & Zaragoza & 2.37 \\
\hline \multicolumn{3}{|c|}{ Scenario 2 (20 km mov. without SS) } & \multicolumn{3}{|c|}{ Scenario 5 (20 km mov. with SS) } \\
\hline Name & Prov. & $\mathrm{dPC}_{\text {conn }}$ & Name & Prov. & $\mathrm{dPC}_{\text {conn }}$ \\
\hline Paramera de Molina & Guadalajara & 6.65 & (SS) Alba & Teruel & 12.12 \\
\hline Layna & Soria & 4.58 & Segura de los Baños & Teruel & 10.24 \\
\hline Altos de Barahona & Soria & 3.57 & (SS) Rubielos de la Cérida & Teruel & 10.20 \\
\hline Gelsa & Zaragoza & 2.60 & Villar del Salz & Teruel & 8.32 \\
\hline Maranchón & Guadalajara & 1.55 & Altiplano de Teruel & Teruel & 8.26 \\
\hline Villar del Salz & Teruel & 1.30 & Blancas & Teruel & 5.97 \\
\hline Azaila & Teruel & 1.28 & (SS) Ojos Negros 1 & Teruel & 5.25 \\
\hline Alforque & Zaragoza & 1.25 & (SS) Hoz de la Vieja & Teruel & 5.08 \\
\hline Blancas & Teruel & 1.03 & (SS) Moneva & Zaragoza & 4.75 \\
\hline Altiplano de Teruel & Teruel & 0.91 & Paramera de Molina & Guadalajara & 4.41 \\
\hline \multicolumn{3}{|c|}{ Scenario 3 (100 km mov. without SS) } & \multicolumn{3}{|c|}{ Scenario 6 (100 km mov. with SS) } \\
\hline Name & Prov. & $\mathrm{dPC}_{\text {conn }}$ & Name & Prov. & $\mathrm{dPC}_{\text {conn }}$ \\
\hline Layna & Soria & 8.28 & Segura de los Baños & Teruel & 7.91 \\
\hline Segura de los Baños & Teruel & 8.22 & Layna & Soria & 4.90 \\
\hline Paramera de Molina & Guadalajara & 7.89 & (SS) Rubielos de la Cérida & Teruel & 4.09 \\
\hline Altos de Barahona & Soria & 7.08 & (SS) Alba & Teruel & 4.07 \\
\hline Altiplano de Teruel & Teruel & 3.78 & Altiplano de Teruel & Teruel & 4.03 \\
\hline Blancas & Teruel & 3.60 & Altos de Barahona & Soria & 3.97 \\
\hline Maranchón & Guadalajara & 2.86 & Paramera de Molina & Guadalajara & 3.80 \\
\hline Azaila & Teruel & 2.52 & (SS) Pinilla Trasmonte & Burgos & 3.48 \\
\hline Lécera & Zaragoza & 2.50 & (SS) Hoz de la Vieja & Teruel & 3.06 \\
\hline Gelsa & Zaragoza & 2.16 & Villar del Salz & Teruel & 2.76 \\
\hline
\end{tabular}




\section{Table 4 (on next page)}

Summary of the 10 most important nodes for the connectivity based on the global index dPC.

Stepping stones are indicated as 'SS'. See the complete list in Supplemental Data S2. 


\begin{tabular}{|c|c|c|c|c|c|}
\hline \multicolumn{3}{|c|}{ Scenario 1 (5 km mov. without $\mathrm{SS})$} & \multicolumn{3}{|c|}{ Scenario 4 (5 km mov. with SS) } \\
\hline Name & Prov. & $\mathrm{dPC}$ & Name & Prov. & $\mathrm{dPC}$ \\
\hline Monegros & Zaragoza & 40.99 & Monegros & Zaragoza & 28.96 \\
\hline Blancas & Teruel & 21.29 & Blancas & Teruel & 25.30 \\
\hline Torralba de los Frailes & Teruel & 9.98 & Paramera de Molina & Guadalajara & 12.33 \\
\hline Paramera de Molina & Guadalajara & 9.10 & (E) Alba & Teruel & 11.22 \\
\hline Gelsa & Zaragoza & 8.99 & Torralba de los Frailes & Teruel & 9.49 \\
\hline Bardenas & NA & 2.64 & Villar del Salz & Teruel & 7.96 \\
\hline Pinilla del Campo & Soria & 2.51 & Gelsa & Zaragoza & 7.37 \\
\hline Lécera & Zaragoza & 2.27 & (E) Rubielos de la Cérida & Teruel & 7.35 \\
\hline Orihuela del Tremedal & Teruel & 1.90 & Pozondón & Teruel & 6.83 \\
\hline La Torresaviñán & Guadalajara & 1.77 & (E) Cuerlas 1 & Zaragoza & 6.43 \\
\hline \multicolumn{3}{|c|}{ Scenario 2 (20 km mov. without $\mathrm{SS})$} & \multicolumn{3}{|c|}{ Scenario 5 (20 km mov. with $S S)$} \\
\hline Name & Prov. & $\mathrm{dPC}$ & Name & Prov. & $\mathrm{dPC}$ \\
\hline Monegros & Zaragoza & 33.79 & Blancas & Teruel & 24.70 \\
\hline Blancas & Teruel & 26.85 & Monegros & Zaragoza & 20.46 \\
\hline Paramera de Molina & Guadalajara & 15.37 & (E) Alba & Teruel & 14.04 \\
\hline Torralba de los Frailes & Teruel & 13.62 & Segura de los Baños & Teruel & 11.67 \\
\hline Gelsa & Zaragoza & 11.10 & (E) Rubielos de la Cérida & Teruel & 10.93 \\
\hline Layna & Soria & 5.77 & Altiplano de Teruel & Teruel & 10.31 \\
\hline Altos de Barahona & Soria & 4.89 & Paramera de Molina & Guadalajara & 9.84 \\
\hline Belchite & Zaragoza & 4.73 & Villar del Salz & Teruel & 9.40 \\
\hline Lécera & Zaragoza & 4.42 & Torralba de los Frailes & Teruel & 8.76 \\
\hline Alforque & Zaragoza & 3.89 & Belchite & Zaragoza & 6.74 \\
\hline \multicolumn{3}{|c|}{ Scenario 3 (100 km mov. without SS) } & \multicolumn{3}{|c|}{ Scenario 6 (100 km mov. with SS) } \\
\hline Name & Prov. & $\mathrm{dPC}$ & Name & Prov. & $\mathrm{dPC}$ \\
\hline Blancas & Teruel & 27.40 & Monegros & Zaragoza & 17.19 \\
\hline Monegros & Zaragoza & 25.50 & Blancas & Teruel & 16.28 \\
\hline Paramera de Molina & Guadalajara & 15.06 & Segura de los Baños & Teruel & 9.14 \\
\hline Torralba de los Frailes & Teruel & 12.05 & Paramera de Molina & Guadalajara & 7.69 \\
\hline Segura de los Baños & Teruel & 10.18 & Torralba de los Frailes & Teruel & 6.60 \\
\hline Lécera & Zaragoza & 10.06 & Belchite & Zaragoza & 6.20 \\
\hline Layna & Soria & 9.67 & Layna & Soria & 5.59 \\
\hline Altos de Barahona & Soria & 8.67 & Altiplano de Teruel & Teruel & 5.46 \\
\hline Gelsa & Zaragoza & 7.70 & (E) Alba & Teruel & 5.36 \\
\hline Belchite & Zaragoza & 7.08 & Lécera & Zaragoza & 5.17 \\
\hline
\end{tabular}

